\title{
РОЛЬ САМОСТІЙНОЇ РОБОТИ СТУДЕНТІВ У ФОРМУВАННІ ПРОФЕСІЙНОЇ КОМПЕТЕНЦІЇ
}

\section{Прокопенко Н. В.}

\section{ВСТУП}

Сучасна вища освіта змінює вектор від підготовки фахівця вузької спрямованості до підготовки випускника, здатного постійно самостійно придбавати знання, уміння, проявляти творчу активність, ініціативність, готового до ухвалення рішень, який демонструє широку професійну ерудицію. Вирішенню цих завдань сприяє високий рівень самостійної пізнавальної, навчально-професійної роботи студентів, сформованої в період професійної освіти.

У наш час відбувається посилення ролі самостійної роботи студентів у ЗВО, що визначено в сучасній особово-орієнтованій освітній парадигмі.

Особово-орієнтований підхід, який $\epsilon$ принципом організації самостійної роботи студентів, вимагає врахування особистих якостей студентів, а також розглядає особу студента як суб'єкта самостійної діяльності, видається найбільш відповідним підходом до організації самостійної роботи. Особово-орієнтований підхід дає можливість кожному студентові реалізовувати себе в навчальній самостійній діяльності 3 опорою на свої схильності й інтереси, можливості, здібності та суб'єктивний досвід. Для реалізації особово-орієнтованого підходу під час формування професійних компетенцій потрібно створювати педагогічні умови, необхідні для ефективної реалізації самостійної роботи студентів, тобто кожен студент має отримувати індивідуальні завдання 3 урахуванням рівня його підготовки та його можливостей.

Досить ефективними способами організації формування професійної компетенції з використанням самостійної роботи є ділова гра, участь у конференціях, підготовка відповідей з презентаціями.

\section{1. Самостійна робота студентів як необхідний складник навчального процесу}

Самостійна робота студентів $є$ обов'язковим складником навчального процесу, здійснюється в різних формах навчального діяльності, де можна набути практичного досвіду, додаткові знання й 
навички. На відміну від аудиторного зайняття, яке досить жорстко регламентоване, самостійна робота студента дає відносну свободу у виборі способів реалізації цієї діяльності з урахуванням установлених обмежень у навчальному процесі ${ }^{1}$.

Загалом самостійну роботу можна визначити досить різноманітно:

- самостійний пошук необхідної інформації, отримання знань, використання цих знань для вирішення начальних, наукових i професійних завдань;

- діяльність студентів із засвоєння знань і вмінь, яка протікає без безпосереднього керівництва викладача, хоча й спрямовується ним;

- діяльність, що складається 3 багатьох елементів: творчого сприйняття та осмислення навчального матеріалу в ході лекції, підготовки до занять, іспитів, заліків, виконання курсових і дипломних робіт;

- різноманітні види індивідуальної й групової пізнавальної діяльності студентів на занятті або в позааудиторний час без безпосереднього керівництва, але під спостереженням викладача.

Як форма навчання самостійна робота - це форма організації пізнавальної діяльності студентів, за якої вони свідомо та активно прагнуть до поставленої мети, долають труднощі без безпосередньої допомоги з чийого-небудь боку в ході виконання роботи.

Як метод навчання самостійна робота - метод оволодіння глибокими знаннями, формування активності й самостійності, розвитку розумових здібностей тих, що навчаються.

Як засіб навчання самостійна робота - це засіб навчання, який у кожній конкретній ситуації засвоєння відповідає конкретній дидактичній меті й завданню; формує в учнів психологічну установку на самостійне систематичне поповнення своїх знань і вмінь, орієнтування в потоці інформаціїㄹ․

3 позиції самого суб'єкта діяльності самостійну роботу розглядають як цілеспрямовану, внутрішньомотивовану, структуровану самим суб'єктом у сукупності виконуваних дій і кориговану їм за процесом і результатом діяльність. Ї̈ї виконання вимагає від суб'єкта досить високого рівня самосвідомості, рефлексивності, самодисципліни, особистої відповідальності.

Отже, можна сказати, що самостійна робота за багатьма визначеннями має такі спільні ознаки: 1) здійснення управління

${ }^{1}$ Гузанов Б.Н., Морозова Н.В. Организация самостоятельной работы студентов вуза в условиях реализации многоуровневой модели обучения : монография. Екатеринбург : Изд-во Рос. гос. проф.-пед. ун-та, 2014. 158 с.

2 Зеер Э.Ф. Психология профессионального образования. Практикум : учебное пособие для студ. учр. высш. проф. образования. Москва : Академия, 2008. 144 с. 
самостійною діяльністю: безпосереднє управління нею викладачем («під керівництвом», «під контролем»); опосередковане («за завданнями», «без особистої участі»); самоуправління; 2) необхідність застосування розумових і (або) фізичних зусиль для досягнення мети, виконання завдань самостійної роботи; 3) формування або наявність активності суб'єкта навчання; 4) формування, набуття, удосконалення студентом необхідної сукупності знань, умінь, навичок для здійснення навчально-пізнавальної діяльності.

Отже, самостійна робота студентів - це засіб навчання, який:

- у кожній конкретній ситуації засвоєння навчального матеріалу відповідає дидактичній меті й завданню;

- формує в студента на кожному етапі його руху від незнання до знання необхідний обсяг і рівень знань, навичок і вмінь для вирішення певного класу пізнавальних завдань і відповідного просування від нижчих до вищих рівнів розумової діяльності;

- формує психологічну установку на самостійне систематичне поповнення своїх знань і розвиває вміння орієнтуватися в потоці наукової та громадської інформації під час вирішення нових пізнавальних завдань;

- $€$ найважливішим знаряддям педагогічного керівництва та управління самостійною пізнавальною діяльністю студентів у процесі навчання.

На сучасному етапі організація самостійної роботи студентів має низку особливостей :

- здійснення самостійної роботи під контролем викладачів;

- використання викладачем комплексних завдань;

- прояв суб'єктної позиції студентів до здійснення самостійної роботи;

- збільшення варіативності видів, форм самостійної роботи студентів від молодших до старших курсів;

- переважання практикоорієнтованих, а не теоретичних завдань;

- наявність завдань, що передбачають групове виконання ${ }^{3}$.

Система самостійної роботи студентів повинна задовольняти основним принципам дидактики, передусім принципам доступності, систематичності й зв'язку теорії з практикою.

Принцип доступності, або подолання труднощів студентами в пізнанні й перетворенні дійсності пов'язаний із необхідністю пошуку викладачем таких способів установлення контакту з кожним студентом, підбору таких методів і засобів навчання, які в максимально сприяли б

\footnotetext{
3 Зимняя И.А. Педагогическая психология : учебное пособие. Ростов на Дону : Феникс, 1997. 480 с.
} 
у більшості 3 них приведенню в рух сил і можливостей, що відповідають цій фазі їхнього розумового, морально-соціального та фізичного розвитку.

Принцип систематичності полягає в тому, щоб у процесі викладання йти від простого до складного.

Основа принципу зв'язку теорії з практикою - це розуміння студентами зв'язку між пізнанням дійсності, наслідком чого $є$ теорія, $\mathrm{i}$ практикою.

Реалізація дидактичних принципів повинна відповідати рівню самостійної діяльності студентів. Існують чотири рівні самостійної діяльності студентів, що відповідають їхнім навчальним можливостям:

1) копіюючи дії із заданого зразка;

2) репродуктивна діяльність щодо відтворення інформації про різні властивості об'єкта, що вивчається, в основному не виходить за межі рівня пам'яті;

3) продуктивна діяльність самостійного застосування отриманих знань для вирішення завдань, що виходять за межі відомого зразка;

4) самостійна діяльність щодо перенесення знань під час вирішення завдань в абсолютно нових ситуаціях.

I, відповідно, можна виділити чотири типи самостійних робіт: 1) відтворювальні (репродуктивні) самостійні роботи за зразком; 2) реконструктивно-варіативні; 3) евристичні; 4) творчі ${ }^{4}$.

1. Відтворювальні (репродуктивні) самостійні роботи включають вирішення типових завдань, виконання різних вправ за зразком, а також розуміння матеріалу, що вивчається (робота 3 підручником, опрацювання конспекту лекції тощо). Вони дають змогу засвоювати матеріал, що вивчається, але не розвивають творчої активності. На рівні цієї роботи відбувається відтворення й розуміння того, що вивчається. Цей тип самостійної роботи є важливим через можливість залучати до самостійного опрацювання значного за обсягом масиву навчальної інформації, у тому числі новітньої, що 3 об'єктивних причин не вміщена в підручники, посібники, проте $є$ професійно значущою для формування майбутніх фахівців. Такий тип самостійної роботи доцільно застосовувати для студентів 1 курсу, оскільки 3 такими видами робіт студенти ознайомлені ще зі школи.

2. Роботи реконструктивно-варіативного типу дають змогу на основі отриманих раніше знань і даної педагогом загальної ідеї знайти самостійно конкретні рішення завдань відповідно до заданих умов завдання. Під час виконання роботи цього типу відбувається

4 Денисова Е.А., Николаева Э.Ф., Николаева С.Ю. Организация самостоятельной работы студентов. Тольятти : Изд-во ТГУ, 2016. 78 с. 
відтворення та часткові зміни структури й змісту засвоєної раніше навчальної інформації, результатом цієї роботи є «формування знанькопій і знань, що дають змогу розв'язувати типові завдання». Такий тип самостійної роботи доцільно застосовувати для студентів 2 та 3 курсів, оскільки студенти вже володіють певною кількістю знань, мають навички їх застосування для вирішення нових завдань.

3. Евристичні самостійні роботи передбачають необхідність відтворення не лише функціональної характеристики знань, а й структури знань, залучення відомих знань для вирішення завдань, проблем і ситуацій. Це третій рівень розумової діяльності, на якому відбувається глибше розуміння навчального матеріалу, починається творча активність. Цей тип самостійної роботи також доцільно застосовувати для студентів 2 та 3 курсів. У роботах цього типу збільшується питома вага дослідницького й креативного складника передусім через виконання курсових робіт, певних творчих робіт 5 .

4. Творчі (дослідницькі) самостійні роботи - це завершальний етап розумової діяльності. Студенти розробляють і пропонують свої рішення проблемних ситуацій, аналітичних і дослідницьких завдань. Цей тип самостійної роботи спрямовано на розвиток творчих (дослідницьких) здібностей. На цьому рівні студенти демонструють сформованість розумової самостійності. До цього типу самостійної роботи належать курсові, дипломні (кваліфікаційні) роботи, робота в наукових гуртках та об'єднаннях, проблемних групах, участь студентів у розробленні науково-дослідницьких тем кафедр, університету тощо. Такі роботи варто застосовувати для студентів 4 i 5 курсів $^{6}$.

Під час виконання самостійних робіт виокремлених типів пізнавальна активність і самостійність суб'єктів навчання виражається в їхніх узагальненнях проблемних ситуацій, у розмежуванні суттєвого $\mathrm{i}$ другорядного, а також у відшукуванні способу виконання в межах вирішення відповідних завдань. За таких умов суб'єкт навчання залучає та варіює в процесі виконання завдань переважно елементи свого формалізованого досвіду, проте наявні знання зазвичай використовує в новій функції, завдяки чому виникає продуктивний процес одержання нової інформації, тобто під час виконання завдань певного типу накопичується новий досвід діяльності на рівні оволодіння елементарними методами дослідження в окремих навчальних дисциплінах, закладаються основи формування вмінь переносити ці методи на більш широкий діапазон суміжних дисциплін.

\footnotetext{
5 Зимняя И.А. Педагогическая психология : учебное пособие. Ростов на Дону : Феникс, 1997. 480 с.

${ }^{6}$ Там же.
} 
Традиційними видами самостійної роботи студентів є такі:

- ведення конспекту лекцій. Це найважливіше джерело інформації під час підготовки до семінарського, практичного й лабораторного зайняття, до виконання письмових робіт усіх видів, до складання заліків та іспитів;

- підготовка до практичних i семінарських занять включає опрацювання лекційного матеріалу, вивчення рекомендованої літератури та іншої інформації по темі, що вивчається;

- підготовка до опитування й колоквіуму, що проводиться в рамках практичного або семінарського зайняття, вимагає з'ясування питань, винесених на конкретне зайняття, підготовки виступів, повторення основних термінів, запам'ятовування алгоритмів;

- підготовка до тестування вимагає ретельнішого вивчення матеріалу по темі або блоку тем, акцентування уваги на визначеннях термінів, змісті понять, алгоритмах;

- підготовка до аудиторної контрольної роботи аналогічна попередній формі, але акцент робиться на вивчення методик і формул розрахунку, з'ясування змісту розрахункових показників;

- підготовка рефератів, доповідей та есе. Їх мета - навчити студента користуватися літературою, статистичними даними, критично осмислювати теорію і практику цих проблем, привносити до тексту полеміку, допомогти студентові набути навичок науково-дослідної роботи, прищепити йому вміння чітко й логічно викладати матеріал письмово;

- написання курсових робіт (проектів) є самостійним науковопрактичним дослідженням 3 певної теми, у ході якого студенти розвивають навички роботи 3 науковою, навчальною, спеціальною літературою, документами, довідковими матеріалами; опановують методи пошукової діяльності, обробки, узагальнення, аналізу інформації; отримують знання 3 предмету й розширюють загальний кругозір; вирішують практичні завдання на основі теоретичних знань; активізують самостійну роботу і творче мислення;

- оформлення звітів з практики вимагає систематизації вивченого практичного матеріалу, є базою для написання курсових і дипломною робіт;

- написання науково-дослідної роботи має на меті придбання студентами навичок дослідницької діяльності, а також формування активної позиції в процесі навчання;

- підготовка до заліків та іспитів. Цей вид самостійної роботи пов'язаний $з$ обробкою, систематизацією великого обсягу лекційного матеріалу, може грунтуватися на раніше виконаній самостійній роботі, a також супроводжується великим емоційним навантаженням, обумовленим важливістю результату; 
- написання випускної кваліфікаційної (дипломної) роботи найважливіший вид самостійної роботи, що відбиває відповідність випускника кваліфікаційним вимогам освітнього стандарту за фахом.

У системі навчання самостійна робота виконує такі функції:

- навчальна функція полягає в ії сприянні активному освоєнню студентами змісту освітньої програми, формуванню первинного досвіду рішення професійних завдань;

- розвивальна функція виражається в інтелектуальному, емоційновольовому розвитку студентів, залученні до дослідницької, творчої діяльності;

- виховна функція полягає у формуванні в студентів потреби в самоосвіті, активної життєвої позиції;

- стимулювальна функція проявляється в наданні процесу навчання професійного прискорення, тобто в студентів формується вміння бачити горизонти особистого професійного зростання й прагнення їх досягти.

Отже, самостійна робота студентів є найважливішим складником процесу підготовки кваліфікованих кадрів, що забезпечує розвиток їхньої особистості.

\section{2. Формування професійної компетенції за допомогою самостійної роботи}

Сьогодні все більшого значення набуває система особовоорієнтованого навчання й формування відповідного методичного, дидактичного забезпечення навчального процесу.

Особово-орієнтоване навчання - це таке навчання, де на перше місце ставиться сама особа, іiі самобутність, самоцінність. Ціннісною системою стосунків на всіх рівнях освітнього процесу $є$ суб'єктсуб'єктна взаємодія, усередині якої суб'єктний досвід кожного іiі учасника спочатку розкривається, а потім узгоджується зі змістом навчання. Особово-орієнтоване навчання виходить із визнання унікальності суб'єктного досвіду студента як важливого джерела індивідуальної життєдіяльності, що проявляється, зокрема, у пізнанні, тим самим визнається, що в освіті відбувається не просто інтеріоризація учнями заданих педагогічних дій, а «зустріч» досвіду, що задається, і суб'єктного, своєрідне «окультурення» останнього, його збагачення, приріст, перетворення, що і становить «вектор» індивідуального розвитку ${ }^{7}$.

7 Бондаревская Е.В. Ценностные основания личностно-ориентированного воспитания. Педагогика. 2007. № 8. С. 44-53. 
Реалізація особово-орієнтованої технології в професійному освітньому процесі вимагає врахування таких вимог:

- наявності чіткої мети й діагностичності завдань цілей навчання;

- наявності навчального матеріалу у вигляді системи пізнавальних і практичних завдань, ситуацій, завдань, проектів і вправ;

- наявності послідовності, логіки етапів виконання навчальних завдань;

- указівки способів взаємодії учасників професійного освітнього процесу;

- мотиваційного забезпечення суб'єктів педагогічної діяльності навчання з орієнтацією на реалізацію їхніх особових функцій ${ }^{8}$.

Стосовно організації самостійної роботи студентів у ЗВО особовоорієнтований підхід спрямований на розвиток і саморозвиток особи студента: в оволодінні процесами самості (самоактуалізація, самоорганізація, самореалізація, самопрезентація), у розвитку інтелектуальних умінь, а також у здатності до самопрезентації особових досягнень в інформаційних освітніх системах (включаючи вміння використання ресурсів Інтернет).

Основними принципами організації особово-орієнтованої самостійної роботи є такі:

- принцип особового цілеполагання студентів;

- принцип опори на суб'єктний досвід студентів;

- принцип ситуативності організації самостійної роботи студентів;

- принцип розвитку комунікативних здібностей особи за допомогою інформаційних технологій;

- принцип продуктивності самостійної роботи студентів;

- принцип освітньої рефлексії9.

Організація самостійної роботи студентів має будуватися відповідно до особово-орієнтованих принципів. Отже, під час організації цієї роботи необхідно допомогти студентам здійснити самостійну роботу, усвідомити свої потреби, навчити студента ставити цілі своєї самостійної діяльності, викликати його особову мотивацію й свідомо управляти процесом, створювати освітню продукцію й рефлексувати.

Активна самостійна робота студентів можливо за умови стійкої мотивації. Іншими словами, головне завдання викладача в організації полягає в тому, щоб навчити кожного студента самостійно використати свій мотиваційний, інтелектуальний, творчий ресурс у виконанні

8 Завьялова М.С. Личностно-ориентированный подход к организации модульнорейтингового обучения студентов : дисс. ... канд. пед. наук : 13.00.01. Саратов, 2011. 189 с.

9 Киселева Н.А. Новые педагогические и информационные технологии в образовании : монография. Нижнекамск : Изд-во НМИ «Чишмэ», 2004. 92 с. 
завдань роботи. При цьому позитивна мотивація $є$ пусковим механізмом виконання самостійної роботи. Студент повинен виступати як активний і високомотивований суб'єкт самостійної роботи.

Викладач здійснює організацію самостійної діяльності студента й управління нею, стимулюючи розвиток суб'єктності студентів. Особово-орієнтований підхід до самостійної роботи передусім спрямований на особу i припускає високу індивідуалізацію й диференціацію навчання. До складу особового (суб'єктного) досвіду входять, по-перше, предмети, уявлення, поняття; по-друге, операції, прийоми, правила виконання дій, а також способи навчальної роботи; нарешті, по-третє, емоційні коди (особові сенси, установки, стереотипи).

В організації самостійної роботи, яка дає змогу реалізувати принципи особово-орієнтованого навчання, основними принципами $€$ такі:

- розроблення комплексу варіативних завдань/вправ різної спрямованості;

- диверсифікація змісту навчання, форм взаємодії студентів один із одним і 3 навчальними об'єктами (текстовою інформацією, проблемними ситуаціями тощо);

- використання різних видів (способів) діяльності;

- актуалізації особового досвіду у внутрішньому діалозі й у спілкуванні, а також створення ситуацій самовизначення та самовираження (пріоритет Я-ролі);

- варіювання умов, завдань, режимів роботи;

- поточний моніторинг особового зростання того, хто навчається, на основі комплексу критеріїв ${ }^{10}$.

Реалізація особово-орієнтованого навчання $€$ основою для формування професійної компетенції студентів. Професійну компетентність можна розглядати як інтегральну характеристику ділових якостей фахівця й особистих якостей, що відбивають достатній рівень знань і вмінь, щоб здійснити мету цього роду діяльності. Це багатовимірна структура, у яку включають індивідуальні здібності, знання, уміння, навички, досвід, поведінку людини.

Формування професійних компетенцій відбувається в рамках самостійної роботи студентів, оскільки фахівець, затребуваний сьогодні, повинен не просто володіти певним набором знань, умінь, навичок, а й бути готовим до самостійного ухвалення рішень,

10 Бирюкова Н.А. Оценка личностного развития взрослого как индикатор качества дополнительного образования. Интеграция образования. 2016. Т. 20. № 2. C. 238-244. 
самостійного отримання додаткових знань, підвищення кваліфікації в процесі всієї професійної діяльності.

Практикуються такі форми самостійної роботи:

- аналітичний розгляд наукової публікації;

- презентація - вибір студентом певної теми чи проблеми для презентації або висловлення свого бачення, розуміння або нерозуміння цієї проблеми;

- підготовка аналізу конкретної виробничої ситуації, підготовка до ситуаційних вправ;

- підготовка до ділової гри, рольової або командної;

- підготовка групового проекту;

- практикум із навчальної дисципліни, тренінгові програми 3 використанням програмного забезпечення;

- виконання й захист науково-дослідної роботи.

Найцікавішими формами організації самостійної роботи при особово-орієнтованому підході 3 метою формування професійної мотивації є такі.

Ділова гра - створює великі можливості для повторення, закріплення, поглиблення знань, тобто вміння застосовувати знання комплексно, у ситуаціях, що моделюють професійну діяльність майбутнього фахівця, за умови, що ролі в грі прописують і розвивають самі студенти в рамках заданої викладачем професійної ситуації. Так відбувається спілкування, зростає інтерес до нестандартних шляхів вирішення завдань, відповідальність за виконання завдання кожного студента.

Участь студентів у практичних конференціях випускаючої кафедри. Ця форма самостійної роботи ефективна за умови вибору самим студентом тематики доповіді, максимально самостійної підготовки доповіді, виступу.

Підготовка відповідей на додаткові питання 3 підготовкою презентації. Це робить заняття сучасним, цікавим, динамічним. Тут учні розкривають свої творчі здібності ${ }^{11}$.

Проаналізуємо формування професійних компетенції під час використання ділової гри. Прикладом гри може бути гра «Біля озера» 12 .

Дія гри розгортається в умовній господарській системі, що складається 38 промислових підприємств, розташованих на березі

11 Чернякова Ж. Інновації в управлінні самостійною роботою студентівбакалаврів: теоретичні та методологічні засади. Проблеми інноваційного розвитку вищої освіти у глобальному, регіональному та національному контекстах : монографія / за заг. ред. А.А. Сбруєвої та Г.Ю. Ніколаї. Суми : Вид-во СумДПУ імені А. С. Макаренка, 2017. С. 387-410.

${ }^{12}$ Комаров В.Ф. У озера (Игровой комплект). Москва : Аргус, 1994. 26 с. 
озера. Підприємства роблять продукцію, для виготовлення якої потрібна вода. Цю воду підприємства беруть з озера. Відпрацьована в процесі виробництва забруднена вода також скидається в озеро. Для кожного з підприємств упродовж одного технологічного циклу, рівного місяцю, може бути реалізовано одне з таких п'яти рішень:

1) скидання неочищених стоків;

2) очищення води, що скидається;

3) зміна продукції;

4) застосування штрафних санкцій до забрудників озера;

5) преміювання тих, хто очищає стоки.

У першому випадку (рішення «Скидання») підприємство отримує досить великий прибуток за цей технологічний цикл у зв'язку з економією на дорогому очищенні води. Проте кожне скидання неочищених стоків погіршує стан озера, отже, якість води, що з нього забирається. Це призводить до зниження прибутку на всіх підприємствах упродовж наступних технологічних циклів, оскільки усім їм доводиться нести додаткові витрати на очищення забираної води.

У другому випадку (рішення «Очищення») підприємство отримує менший прибуток за цей технологічний цикл, не завдаючи при цьому збитку якості води в озері (зрозуміло, такий збиток не виключений з боку інших підприємств).

У третьому випадку (рішення «Зміна продукції») підприємство переходить на випуск продукції, що не вимагає використання води. Це забезпечуе йому постійний, але дуже маленький прибуток, який не залежить від якості води в озері. Зрозуміло, що в цьому випадку це підприємство в поточному технологічному циклі не впливає на стан озера.

У четвертому випадку (рішення «Штраф») керівництво підприємства, замість того щоб займатися виробництвом, здійснює пошук і покарання забрудників водойми впродовж усього поточного місяця. За правилами гри, виявляються всі підприємства, що здійснили в цьому місяці «Скидання», при цьому, замість великого прибутку, вони отримують штраф. Але й той, що штрафує, зазнає деякі збитки за результатами цього технологічного циклу, адже він, замість своєї основної роботи, виконував у цей період контролюючі функції.

У п’ятому випадку (рішення «Премія») керівництво підприємства, замість того щоб займатися виробництвом, здійснює роботи із забезпечення ефективної доочистки стоків з інших підприємств на власних очисних спорудах. У результаті кожне підприємство, яке передає йому на доочистку заздалегідь очищені стічні води, отримує додатковий прибуток. Але ніщо не дається дарма: підприємство, що здійснює доочистку, за результатами цього технологічного циклу зазнає деякі збитки. 
Один раз у 12 місяців у результаті весняного паводку відбувається самоочищення озера, що зумовлює підвищення якості його води. Зазвичай після паводку прибуток на всіх підприємствах, що використовують воду в технологічному процесі, підвищується, оскільки зменшуються витрати на попереднє очищення стічної води.

У грі беруть участь 8 команд (тобто 8-16 учасників), кожна команда виконує дії керівника підприємства. Гра протікає у вигляді періодів, рівних місячному технологічному циклу, усього гра може начитувати до 48 виробничих циклів.

У кожному періоді гравці приймають рішення - одне з розглянутих п'яти. Кожному рішенню, прийнятому на поточний місяць, відповідає певний розмір прибутку або збитків, що отримуються за підсумками діяльності підприємства за цей період. Завдання учасника гри отримати максимальний сумарний прибуток за підсумками своєї діяльності. Крім того, метою всіх учасників $є$ катастрофічно не погіршити якість води, оскільки це єдине джерело води для виробництва й від якості води залежать економічні результати діяльності підприємства.

Величини отриманого прибутку, збитків фіксуються на спеціальних картках.

Усі рішення в грі приймаються анонімно, учасники гри можуть лише здогадуватися, хто конкретно скинув неочищені стоки в озеро в поточному періоді, тобто хто $є$ винуватцем погіршення якості води в озері.

В ігрову схему закладена можливість координації своїх дій учасниками гри. Для цього кожен восьмий місяць проводяться трихвилинні наради, на яких гравці можуть домовитися між собою про ті або інші дії в подальші місяці. Проте, за правилами гри, ці угоди мають рекомендаційний характер. Будь-який гравець заради особистої вигоди має можливість порушити досягнуті домовленості, що може дати йому помітні додаткові економічні переваги перед іншими.

Досить очевидно, що всім гравцям вигідно не забруднювати озеро. Це дає змогу кожному 3 них отримати великий сумарний прибуток, тобто добре реалізувати свої цільові спрямування. Найкращі результати дають стратегії, коли всі гравці приймають рішення «Очищення», а один, по черзі, - рішення «Премія» або ж коли всі приймають рішення «Зміна продукції».

Практика проведення гри показує, що завжди знаходяться гравці, що намагаються отримати надприбуток за рахунок інших. Саме вони починають приймати рішення «Скидання», що призводить до досить швидкого, хоча часто й непомітного на перших порах забруднення озера. 
Зазвичай у грі формується чотири типи персонажів, що відрізняються стилем поведінки:

a) індивідуаліст удачливий - гравець, який зробив за гру значну кількість скидань, із яких оштрафованою виявилася менше ніж половина;

б) індивідуаліст неудачливий - гравець, який зробив за гру значну кількість скидань, із яких більше ніж половина оштрафована;

в) громадський діяч пасивний - гравець, який прийняв незначну кількість рішень «Скидання», «Штраф» і «Премія»;

г) громадський діяч активний - гравець, який прийняв приблизно однакову кількість рішень «Скидання» та «Штраф» і «Премія».

Найбільш удачливими в грі $є$ пасивні громадські діячі й удачливі індивідуалісти.

Ділова гра «Біля озера» застосована для проведення практичного заняття 3 дисципліни «Раціональне природокористування» для студентів-екологів 4 курсу. У грі брали участь 17 студентів, тобто сформовано 7 команд по 2 студента, 1 команда 33 студентів.

Перед початком гри задаються характеристики виробництва, що забруднюють воду озера, речовини, що потрапляють у воду, їх концентрації, характеристики системи очищення стоків.

За умовами гри, 3 підприємства було харчової галузі (кондитерське (2 підприємства), молочне виробництво), 2 підприємства текстильного виробництва, 3 підприємства машинобудівельного виробництва.

Як самостійну роботу студенти виконували аналіз складу (кількісний і якісний) стічних вод підприємства, систем очистки стічних вод. Також аналізували можливості доочищення стічних вод, можливості їх оборотного використання, можливості скидання очищених стічних вод у водойми різного призначення (тобто можливість здійснення в озері рибогосподарської діяльності, рекреаційної діяльності).

Аналіз проведення самостійної підготовки до проведення гри показав таке:

1. Активну участь в аналізі якісного та кількісного складу стічних вод брали 9 студентів (53\%), брали участь в обговоренні окремих питань 5 студентів (29\%), не брали участі в обговоренні 3 студенти $(17 \%)$.

2. Розробляли стратегію гри своєї команди на весь період гри (48 виробничих циклів) 10 студентів (59\%), на менший період 5 студентів (29\%), не планували стратегічних дій - 2 студенти (11\%), притому саме ці студенти сформували одну з команд.

3. Аналіз можливих варіантів своїх рішень, рішень інших команд $і$ їх взаємного впливу проведено 5 студентами (29\%), до результатів їх 
аналізу пізніше прислухалися 10 студентів (59\%), 2 студенти сказали, що «коли почнеться гра, тоді й будемо думати про стратегію».

4. Учасники гри відразу відмовилися від рішення «Зміна продукції», мотивуючи це тим, що вони не знають економічної ефективності цього рішення.

5. Необхідність розробити спільну стратегію для всіх команд, але переваги такої підтримали спочатку 4 студенти (23\%), які потім переконали в необхідності такої стратегії ще 10 студентів (59\%), 3 студенти сказали, що така стратегія є зайвою.

Для формування загальної стратегії учасникам гри необхідно постаратися виробити скоординовані дії на кожному етапі виробничого циклу, показати вигоду цього рішення й переконати інших учасників діяти в рамках цього скоординованого рішення. Скоординована дія створюється на підгрунті інформації про характер виробництва на підприємствах, характеристиках забруднюючих речовин, які потрапляють в озеро, технічних можливостях підприємств та економічної доцільності створення ефективної системи очищення стічних вод. Ці види самостійної роботи студентів відповідають евристичній і творчій самостійній роботі. Виконання такої роботи $€$ цілком можливим і доцільним для студентів 4 курсу.

\section{ВИСНОВКИ}

Сьогодні найбільш затребуваною в суспільстві стала творча, мобільна особа, що має творчу усвідомлену позицію та гнучку адаптацію до всіх змін. Серед особистих якостей вагоме значення має наявність у майбутніх фахівців будь-якого профілю певних здібностей $\mathrm{i}$ вмінь добувати знання 3 різних джерел, систематизувати отриману інформацію, давати оцінку конкретній виробничій ситуації. Формування такого вміння відбувається впродовж усього періоду навчання за допомогою участі студентів у різних видах аудиторної, головне, самостійної роботи.

Самостійна робота як засіб організації навчального або наукового пізнання студента $є$ навчальним завданням, тобто об'єктом діяльності студента, пропонованим викладачем або методичним посібником, а також формою прояву певного способу діяльності 3 виконання відповідного навчального завдання.

Нині виділяють 4 типи самостійної роботи залежно від міри прояву творчої активності студентів, що робить можливим широке використання самостійної роботи впродовж усього навчання.

Самостійна робота студентів відіграє важливу роль у формуванні їхніх професійних компетенцій. Найцікавішими формами можна вважати ділові ігри, підготовка виступів на конференції випускаючих 
кафедр. Однією 3 ділових ігор є гра «Біля озера», у якій учасникам необхідно найраціональніше використати природний ресурс - воду озера, отримуючи при цьому максимальний прибуток від господарської діяльності. Підготовка до проведення цієї гри має самостійний характер і сприяє розвитку професійної компетенції. Як показали результати проведення гри студентами-екологами 4 курсу, вони успішно самостійно моделюють забруднення вод унаслідок скидання різною мірою очищених стічних вод підприємств різних галузей, визначають основні забруднюючі речовини в стічних водах, їх можливі концентрації й оптимальні схеми очищення. Також розробляють спільну стратегію поведінки для отримання максимального прибутку та мінімізації забруднення води.

\section{АНОТАЦІЯ}

Самостійна робота студентів $€$ обов'язковим складником навчального процесу, яка здійснюється в різних формах. Виділяють 4 типи самостійної роботи студентів (відтворювальні (репродуктивні), реконструктивно-варіативні, евристичні, творчі (дослідницькі)), які розрізняються ступенем розвитку творчих (дослідницьких) здібностей. Різні типи самостійної роботи використовують на всіх курсах навчання студентів, від першого до п'ятого. Цікавими сучасними формами організації самостійної роботи студентів $є$ ділова гра (за умови самостійної підготовки до неї, розроблення стратегії проведення гри), підготовка до виступів на конференціях (особливо конференції випускаючих кафедр). Однією з ділових ігор є еколого-економічна гра «Біля озера», яку проведено зі студентами-екологами 4 курсу. Як самостійну підготовку до гри студентам запропоновано провести аналіз складу стічних вод, розробити схеми очистки води, розробити стратегію ігрової поведінки учасників 3 метою досягнення максимального економічного прибутку від господарської діяльності й мінімізації забруднення озера. Така самостійна робота належить до творчих (дослідницьких). За результатами аналізу самостійної підготовки до проведення гри 59\% студентів виконали поставлені завдання, проявили активність у розробленні спільної стратегії.

\section{ЛIТЕРАТУРА}

1. Гузанов Б.Н., Морозова Н.В. Организация самостоятельной работы студентов вуза в условиях реализации многоуровневой модели обучения : монография. Екатеринбург : Изд-во Рос. гос. проф.-пед. ун-та, 2014. $158 \mathrm{c}$.

2. Зеер Э.Ф. Психология профессионального образования. Практикум : учебное пособие. Москва : Академия, 2008. 144 с. 
3. Зимняя И.А. Педагогическая психология : учебное пособие. Ростов-на-Дону : Феникс, 1997. 480 с.

4. Денисова Е.А., Николаева Э.Ф., Николаева С.Ю. Организация самостоятельной работы студентов. Тольятти : Изд-во ТГУ, 2016. 78 с.

5. Бондаревская Е.В. Ценностные основания личностноориентированного воспитания. Педагогика. 2007. № 8. С. 44-53.

6. Завьялова М.С. Личностно-ориентированный подход к организации модульно-рейтингового обучения студентов : дисс. ... канд. пед. наук : 13.00.01. Саратов, 2011. 189 с.

7. Киселева Н.А. Новые педагогические и информационные технологии в образовании : монография. Нижнекамск : Изд-во НМИ «Чишмэ», 2004. 92 с.

8. Бирюкова Н.А. Оценка личностного развития взрослого как индикатор качества дополнительного образования. Интегращия образования. 2016. Т. 20. № 2. С. 238-244.

9. Чернякова Ж. Інновації в управлінні самостійною роботою студентів-бакалаврів: теоретичні та методологічні засади. Проблеми інноваційного розвитку вищої освіти у глобальному, регіональному та начіональному контекстах : монографія / за заг. ред. А.А. Сбруєвої та Г.Ю. Ніколаї. Суми : Вид-во СумДПУ імені А.С. Макаренка, 2017. С. 387-410.

10. Комаров В.Ф. У озера (Игровой комплект). Москва : Аргус, 1994. $26 \mathrm{c}$.

\section{Information about the author:} Prokopenko N. V., $\mathrm{PhD}$ in Biological Sciences, Associate Professor at the Ecology Department Kharkiv National Automobile and Highway University 25, Yaroslava Mudrogo str., Kharkov, Ukraine 